\title{
Vincristine sulfate liposomal injection for acute lymphoblastic leukemia [Corrigendum]
}

Soosay Raj TA, Smith AM, Moore AS. Int J Nanomedicine.

2013;8:4361-4369.

On page 4366, Table 1, Notes,

Notes: Reproduced with permission of Wiley and Sons. Moore A, Pinkerton R. Vincristine: can its therapeutic index be enhanced? Pediatr Blood Cancer. 2009;53(7):1180-1187.22

Should read

Notes: Copyright (C) 2009, Wiley-Liss Inc. This material is reproduced with permission of John Wiley and Sons, Inc. Moore A, Pinkerton R. Vincristine: can its therapeutic index be enhanced? Pediatr Blood Cancer. 2009;53(7):1180-1187.22

\section{Publish your work in this journal}

The International Journal of Nanomedicine is an international, peerreviewed journal focusing on the application of nanotechnology in diagnostics, therapeutics, and drug delivery systems throughou the biomedical field. This journal is indexed on PubMed Central,

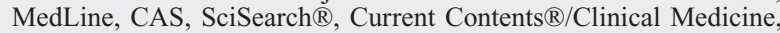

Journal Citation Reports/Science Edition, EMBase, Scopus and the Elsevier Bibliographic databases. The manuscript management system is completely online and includes a very quick and fair peer-review system, which is all easy to use. Visit http://www.dovepress.com/ testimonials.php to read real quotes from published authors. 